\title{
THE POTENTIAL OF PALM OIL MILL EFFLUENT (POME) AS A RENEWABLE ENERGY SOURCE
}

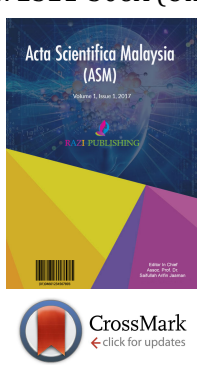

\author{
Nur Izzah Hamna A. Aziz ${ }^{1}$, Marlia M. Hanafiah ${ }^{{ }^{*}}$ \\ ${ }^{1}$ School of Environmental and Natural Resource Sciences, Faculty of Science and Technology, Universiti Kebangsaan Malaysia,
}

\section{Bangi, Selangor, Malaysia}

*Corresponding Author: mhmarlia@ukm.edu.my

This is an open access article distributed under the Creative Commons Attribution License, which permits unrestricted use, distribution, and reproduction in any medium, provided the original work is properly cited.

\begin{tabular}{l} 
ARTICLE DETAILS \\
\hline Article history: \\
Received 19 October 2017 \\
Accepted 19 October 2017 \\
Available online 25 October 2017 \\
Keywords: \\
Palm oil mill effluent (POME), \\
physicochemical characteristic, \\
biodegradable, renewable energy, \\
Malaysia
\end{tabular}

\section{ABSTRACT}

The expanding of oil palm industry has given a significant benefit to the economic growth and country development. However, it has also contributed to environmental problems due to the production of huge quantities of waste and byproducts. Palm oil mill effluent (POME) is a liquid discharge from the palm oil milling process. POME without proper treatment could be harmful to environment because it emitted greenhouse gas emissions into the atmosphere. Therefore, due to its high organic carbon content, POME has currently been applied to generate biogas. This study aims to measure the physicochemical characteristics of untreated POME and the potential of POME as renewable energy. The physicochemical characteristics of raw POME such as chemical oxygen demand (COD), ammonia (NH3N), dry matter (DM) content and heavy metals were also measured and compared with the regulatory discharge limits. Converting POME to biogas can produce energy which save a huge source of renewable energy as well as reduce the environmental impacts of palm oil production.

\section{INTRODUCTION}

The Malaysian palm oil industry has grown greatly in the recent years to become one of the largest palm oil exporters and producers in the world, thus contributes tremendously towards the economy of the country [1]. Therefore, it is important for the palm oil industry to be sustainable to increase its long-term profitability and sustainability. This industry supplied a huge number of byproducts such as empty fruit bunch (EFB), palm fiber and shell that are readily available to be used as energy source $[2,3]$. The flow chart of a typical milling process in Malaysian palm oil mill is shown in Figure 1. The extraction of palm oil involves several processing stages which are sterilization, stripping, digestion, pressing, clarification, purification and vacuum drying $[4,5]$. The most standard and typical way of extracting palm oil in Malaysia is the wet process of palm oil milling [6,7]. A large quantity of water is required at certain stage processes and more than half of this water amount ends up as palm oil mill effluent (POME).

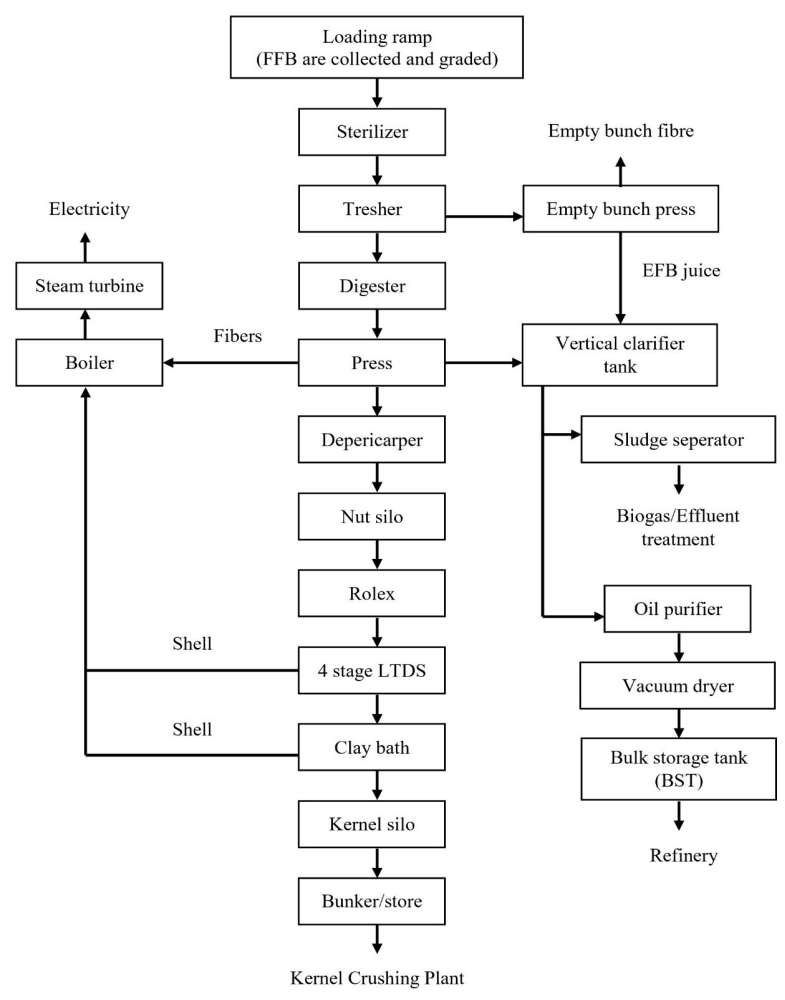

The number of palm oil mills in Malaysia was increasing in the past few years, from about 10 mills in 1960 to 426 operating mills in 2011 [1,7]. However, the sustainability of palm oil production has always been questioned. This is because of the controversy that palm oil plantation causes severe negative impacts on environment such as deforestation and greenhouse gas (GHG) emissions due to over exploration of peat land for oil palm plantation [8,9]. Palm oil mills also contribute to the environmental degradation due to the production of POME generated from the palm oil milling process. Nevertheless, POME is identified as a potential source for generating renewable energy through anaerobic digestion, which give a great advantage to the palm oil industry. Accordingly, the utilization of POME as substrate to produce biogas become popular nowadays especially in Malaysia and Thailand [10,11]. In this study, the physicochemical characteristics of raw POME were measured. The physicochemical characteristics provide a useful and necessary information for the management of POME treatment and determination of the potential of biogas production originated from POME.

\section{MATERIAL AND METHODS}

\subsection{Sampling method}

POME samples were collected from Seri Ulu Langat Palm Oil Mill, Dengkil, Selangor. The mill's main activities were for starch and vegetable fats and oils manufacturing. The samples were taken from the pipeline of fresh fruit bunch (FFB) sterilization process. The POME samples were kept in Schott bottle and stored at $4{ }^{\circ} \mathrm{C}$ for later use in order to prevent microbial decomposition.

\subsection{Apparatus and operation}

A laboratory analysis was done to determine the physicochemical characteristics of POME such as dry matter (DM), organic dry matter (ODM), nutrient analysis, heavy metals analysis, chemical oxygen demand (COD), ammonia test and carbon to nitrogen ratio analysis. The percentage of DM (\%) and ODM (\%) content was determined by using the following formulae according to VDI 4630, 2006 guideline:

$$
\mathrm{DM}=\frac{\text { Dry sample weight }(\mathrm{g})}{\text { Wet sample weight }(\mathrm{g})} \times 100
$$

$\mathrm{ODM}=\frac{(\text { Dry sample }+ \text { porcelain weight })(\mathrm{g})-(\text { Dry porcelain }+ \text { ash weight })(\mathrm{g})}{} \times 100$ 


\subsection{Analytical methods}

Nutrient analysis was conducted by UNIPEQ Sdn. Bhd., UKM. The protein content was determined using in house method No. STP/Chem/A03 based on AOAC 16th Edi. 981.10 and fat content was determined using in house method No. STP/Chem/A02 based on AOAC 16th Edi. 991.36. Total carbohydrate content was determined using in house method No. STP/ Chem/A06 based on Promerance Food Analysis: Theory and Practice, 2nd Ed. (pg 637). In house method No. STP/Chem/A05 based on AOAC 16th Edi. 923.03 and No. STP/Chem/A04 based on AOAC 16th Edi. 950.46 were used to determine ash and moisture content, respectively. Energy content was measured using in house method No. STP/Chem/A01 based on Pearson's The Chemical Analysis of Foods (6th Edition, page 578). Inductively Coupled Plasma Mass Spectrometry (ICP-MS) was used to determine the concentration of heavy metal, while Hach DR 6000 spectrophotometer was used to determine the COD by HACHReactor Digestion Method. The ammonia-nitrogen analysis was also conducted by using Hach DR 6000 spectrophotometer, following the Nessler method. The $\mathrm{C} / \mathrm{N}$ ratio was determined using CHNS analyser.

\section{RESULTS AND DISCUSSION}

Table 1 shows the laboratory analyses results on the physicochemical characteristics of raw POME.

Table 1: Physicochemical characteristics of raw POME

\begin{tabular}{|lcc|}
\hline \multicolumn{1}{c}{ Parameter } & Unit & POME) \\
\hline $\mathrm{pH}$ & - & 4.3 \\
Temperature & ${ }^{\circ} \mathrm{C}$ & 68.2 \\
Ammonia Nitrogen $\left(\mathrm{NH}_{3} \mathrm{~N}\right)$ & $\mathrm{mg} / \mathrm{L}$ & 290 \\
Chemical Oxygen Demand & $\mathrm{mg} / \mathrm{L}$ & 40667 \\
(COD) & & \\
Carbon to Nitrogen $(\mathrm{C} / \mathrm{N})$ ratio & $\mathrm{mg} / \mathrm{L}$ & 49000 \\
$\mathrm{DM}$ & $\% \mathrm{FM}$ & 6.73 \\
$\mathrm{ODM}$ & $\% \mathrm{DM}$ & 94.90 \\
Heavy & & \\
Magnesium, $\mathrm{Mg}$ & $\mathrm{mg} / \mathrm{L}$ & 622.092 \\
Calcium, Ca & $\mathrm{mg} / \mathrm{L}$ & 57.533 \\
Phosphorus, $\mathrm{P}$ & $\mathrm{mg} / \mathrm{L}$ & 124.12 \\
Potassium, $\mathrm{K}$ & $\mathrm{mg} / \mathrm{L}$ & 3553.085 \\
Nutrient & & \\
Protein & $\mathrm{g} / 100 \mathrm{~g}$ & 0.83 \\
Fat & $\mathrm{g} / 100 \mathrm{~g}$ & 0.71 \\
Carbohydrate & $\mathrm{g} / 100 \mathrm{~g}$ & 1.5 \\
Ash & $\mathrm{g} / 100 \mathrm{~g}$ & 0.65 \\
Moisture & $\mathrm{g} / 100 \mathrm{~g}$ & 96.32 \\
Energy & $\mathrm{kcal} / 100 \mathrm{~g}$ & 16 \\
\hline
\end{tabular}

The three major operations that generate POME include sterilizing fresh fruit bunch (FFB), clarifying extracted crude palm oil (CPO) and empty fruit bunch (EFB) processing. POME is a thick and brownish liquid with high solids, oil and grease, COD and BOD values $[12,13]$. Fresh POME is hot with temperature of $68.2{ }^{\circ} \mathrm{C}$ and $\mathrm{pH} 4.3$ (acidic) (Table 1). Although POME is a non-toxic waste, discharging untreated POME into water bodies can adversely affect the ecology of aquatic by depleting the dissolved oxygen (DO) content because POME contains high chemical oxygen demand (COD) $(40,667 \mathrm{mg} / \mathrm{L})$ (Table 1). POME is well known for its high COD value due to its fat contents [14]. POME also contains a significant number of nutrient elements (e.g. Mg, Ca, P, K) which are essential for plant growth. The contents of dissolved constituents such as high concentration of protein fat, carbohydrate and minerals could be converted into useful materials using microbial processes [15].

POME physicochemical characteristics might be slightly different as from previous studies. This is because it might be affected by the time of sample withdrawal and also due to the palm oil production processes in the mills and the quality of the FFB $[15,16]$. Therefore, the experiments were repeated three times for all analyses to obtain average result in order to minimize the differences in the characteristic of POME. Approximately 0.7 $\mathrm{m} 3$ of POME is generated for every ton of fresh fruit bunch (FFB) processed $[2,17]$. Every ton of POME can generate about $28 \mathrm{~m} 3$ of biogas and about 2.4 ton of methane gas can be derived in a year which is equivalent to 3.4 million litres of diesel and the estimated energy generated is $13,600 \mathrm{MWh}$ of electricity.

In Malaysia, about $85 \%$ of POME treatment system is based on conventional biological treatment methods of acidification, anaerobic, facultative and aerobic digestion $[4,18]$. The anaerobic digestion process is a suitable treatment method for rapid disintegration of organic matter to produce biogas that can be utilized for electricity and as energy source $[19,20]$. However, ponding systems in biological treatment methods is quite inefficient due to the high BOD load and low pH of POME as well as colloidal nature of the suspended solids in the POME [12]. In fact, this method also has some disadvantages such as large area of land is needed, relatively long hydraulic retention time (HRT) and difficulty in collecting and utilizing the methane generated which results in harmful effect on the environment. Hence, it is vital to provide a better technology that can overcome all obstacles in the POME treatment [21].

\section{CONCLUSION}

Exploiting organic wastes as source of energy seems a promising alternative for future' generation of energy. One of the main wastes in Malaysia is POME and it can be concluded that POME could be a good source for generating bioenergy due to its high organic contents. Since there were abundant amount of POME were generated in the mills, it would be the most reliable renewable energy source. However, a proper POME treatment management is crucial to ensure a sustainable process in palm oil milling, besides protecting the environment. Thus, palm oil industry will continuously contribute a significant benefit to Agro-based industry and social economic for Malaysia.

\section{ACKNOWLEDGEMENT}

The authors would like to acknowledge the School of Environmental and Natural Resource Sciences, Faculty of Science and Technology, Universiti Kebangsaan Malaysia for the financial and technical support and Seri Ulu Langat Palm Oil Mill for their kind cooperation towards this research. Marlia Mohd Hanafiah was financed by research grants: FRGS/2/2013/ STWN01/UKM/03/1 and TD-2014012.

\section{REFERENCES}

[1] Chin, M. J., Poh, P. E., Tey, B. T., Chan, E. S. and Chin, K. L. 2013. Biogas from Palm Oil Mill Effluent (Pome): Opportunities and Challenges from Malaysia's Perspective. Renewable and Sustainable Energy Reviews, 26(6), 717-726.

[2] Chuah, T., Wan Azlina, A., Robiah, Y. and Omar, R. 2006. Biomass as the Renewable Energy Sources in Malaysia: An Overview. International Journal of Green Energy, 3(3), 323-346.

[3] Mekhilef, S., Saidur, R., Safari, A. and Mustaffa, W. E. S. B. 2011. Biomass Energy in Malaysia: Current State and Prospects. Renewable and Sustainable Energy Reviews, 15(7), 3360-3370.

[4] Loh, S. K., Lai, M. E., Ngatiman, M., Lim, W. S., Choo, Y. M., Zhang, Z. and Salimon, J. 2013. Zero Discharge Treatment Technology of Palm Oil Mill Effluent. Journal of Oil Palm Research, 25(DEC), 273-281.

[5] Vijaya, S., Choo, Y. M., Halimah, M., Zulkifli, H., Tan, Y. A. and Puah, C. W. 2010. Life Cycle Assessment of the Production of Crude Palm Oil (Part 3). Journal of Oil Palm Research, 22, 895-903.

[6] Ibrahim, A. H., Dahlan, I., Adlan, M. N. and Dasti, A. F. 2012. Comparative Study on Characterization of Malaysian Palm Oil Mill Effluent. Research Journal of Chemical Sciences, 2(12), 1-5.

[7] Wu, T. Y., Mohammad, A. W., Jahim, J. M. and Anuar, N. 2010. Pollution Control Technologies for the Treatment of Palm Oil Mill Effluent (Pome) through End-of-Pipe Processes. Journal of Environmental Management, 91(7), 1467-1490.

[8] Lam, M. K. and Lee, K. T. 2011. Renewable and Sustainable Bioenergies Production from Palm Oil Mill Effluent (Pome): Win-Win Strategies toward Better Environmental Protection. Biotechnology Advances, 29(1), 124-141.

[9] Laurance, W. F., Koh, L. P., Butler, R., Sodhi, N. S., Bradshaw, C. J., Neidel, J. D., Consunji, H. and Mateo Vega, J. 2010. Improving the Performance of the Roundtable on Sustainable Palm Oil for Nature Conservation. Conservation Biology, 24(2), 377-381.

[10] Basri, M., Yacob, S., Hassan, M., Shirai, Y., Wakisaka, M., Zakaria, M. and Phang, L. Y. 2010. Improved Biogas Production from Palm Oil Mill Effluent by a Scaled-Down Anaerobic Treatment Process. World Journal of Microbiology and Biotechnology, 26(3), 505-514.

[11] Oswal, N., Sarma, P., Zinjarde, S. and Pant, A. 2002. Palm Oil Mill Effluent Treatment by a Tropical Marine Yeast. Bioresource technology, 85(1), 35-37.

[12] Ahmad, A., Sumathi, S. and Hameed, B. 2005. Adsorption of Residue Oil from Palm Oil Mill Effluent Using Powder and Flake Chitosan: Equilibrium and Kinetic Studies. Water research, 39 (12), 2483-2494. 
[13] Foo, K. Y. and Hameed, B. H. 2010. Insight into the Applications of Palm Oil Mill Effluent: A Renewable Utilization of the Industrial Agricultural Waste. Renewable and Sustainable Energy Reviews, 14(5), $1445-1452$.

[14] Omar, R., Harun, R. M., Mohd Ghazi, T., Wan Azlina, W., Idris, A. and Yunus, R. 2008. Anaerobic Treatment of Cattle Manure for Biogas Production. Proceedings Philadelphia, Annual meeting of American Institute of Chemical Engineers, hlm. 1-10.

[15] Rupani, P. F., Singh, R. P., Ibrahim, M. H. and Esa, N. 2010. Review of Current Palm Oil Mill Effluent (Pome) Treatment Methods: Vermicomposting as a Sustainable Practice. World Applied Sciences Journal, 11(1), 70-81.

[16] Saifuddin, N. and Dinara, S. 2011. Pretreatment of Palm Oil Mill Effluent (Pome) Using Magnetic Chitosan. Journal of Chemistry, 8(S1), S67-S78.

[17] Sumathi, S., Chai, S. and Mohamed, A. 2008. Utilization of Oil Palm as a Source of Renewable Energy in Malaysia. Renewable and Sustainable Energy Reviews, 12(9), 2404-2421.

[18] Zhang, Y., Li, Y., Lina, C., Xiuhua, L., Zhijian, M. and Zhang, Z. 2008. Start-up and Operation of Anaerobic Egsb Reactor Treating Palm Oil Mill Effluent. Journal of Environmental Sciences, 20(6), 658-663.

[19] Linke, B. 2006. Kinetic Study of Thermophilic Anaerobic Digestion of Solid Wastes from Potato Processing. Biomass and Bioenergy, 30(10), 892-896.

[20] Perez, M., Romero, L. and Sales, D. 2001. Organic Matter Degradation Kinetics in an Anaerobic Thermophilic Fluidised Bed Bioreactor. Anaerobe, $7(1), 25-35$.

[21] Hanafiah, M. M., Mohamed Ali, M. Y., Abdul Aziz, N. I. H., Ashraf, M. A., Halim, A. A., Lee, K. E., Idris, M. 2017. Biogas Production from Goat and Chicken Manure in Malaysia. Applied ecology and Environmental Research, 15(3), 529-535. 